\title{
Microstructure and biomechanical characteristics of bone substitutes for trauma and orthopaedic surgery
}

Esther MM Van Lieshout ${ }^{*}$, Gerdine H Van Kralingen ${ }^{1}$, Youssef El-Massoudi ${ }^{1}$, Harrie Weinans ${ }^{2}$, Peter Patka ${ }^{1}$

\begin{abstract}
Background: Many (artificial) bone substitute materials are currently available for use in orthopaedic trauma surgery. Objective data on their biological and biomechanical characteristics, which determine their clinical application, is mostly lacking. The aim of this study was to investigate structural and in vitro mechanical properties of nine bone substitute cements registered for use in orthopaedic trauma surgery in the Netherlands.

Methods: Seven calcium phosphate cements (BoneSource ${ }^{\circledR}$, Calcibon $^{\circledR}$, ChronOS $^{\circledR}$, Eurobone $^{\circledR}$, HydroSet $^{\mathrm{TM}}$, Norian $\mathrm{SRS}^{\circledR}$, and Ostim ${ }^{\circledR}$ ), one calcium sulphate cement $\left(\mathrm{MIIG}^{\circledR} \mathrm{X} 3\right)$, and one bioactive glass cement (Cortoss ${ }^{\circledR}$ ) were tested. Structural characteristics were measured by micro-CT scanning. Compression strength and stiffness were determined following unconfined compression tests.

Results: Each bone substitute had unique characteristics. Mean total porosity ranged from $53 \%$ (Ostim ${ }^{\circledR}$ ) to $0.5 \%$ $\left(\right.$ Norian SRS $\left.{ }^{\circledR}\right)$. Mean pore size exceeded $100 \mu \mathrm{m}$ only in Eurobone ${ }^{\circledR}$ and Cortoss $^{\circledR}(162.2 \pm 107.1 \mu \mathrm{m}$ and $148.4 \pm$ $70.6 \mu \mathrm{m}$, respectively). However, $230 \mu \mathrm{m}$ pores were found in Calcibon ${ }^{\circledR}$, Norian SRS ${ }^{\circledR}$, HydroSetTM $^{\text {TM }}$, and MIIIG ${ }^{\circledR}$ X3. Connectivity density ranged from $27 / \mathrm{cm}^{3}$ for HydroSet ${ }^{\mathrm{TM}}$ to $0.03 / \mathrm{cm}^{3}$ for Calcibon ${ }^{\circledR}$. The ultimate compression strength was highest in $\operatorname{Cortoss}^{\circledR}(47.32 \mathrm{MPa})$ and lowest in Ostim ${ }^{\circledR}(0.24 \mathrm{MPa})$. Young's Modulus was highest in Calcibon ${ }^{\circledR}(790 \mathrm{MPa})$ and lowest in Ostim ${ }^{\circledR}(6 \mathrm{MPa})$.

Conclusions: The bone substitutes tested display a wide range in structural properties and compression strength, indicating that they will be suitable for different clinical indications. The data outlined here will help surgeons to select the most suitable products currently available for specific clinical indications.
\end{abstract}

\section{Background}

Treatment of bone defects is a continuous challenge in skeletal trauma and orthopaedic trauma surgery. Bone graft represents the second most common transplanted tissue, with blood being number one [1]. Worldwide, more than 2.2 million bone grafting procedures are performed annually for the repair of bone defects in orthopaedic traumatology, neurosurgery, and dentistry [2-4]. Approximately $10 \%$ of all skeletal reconstructive surgical interventions require bone grafting [4]. Large defects resulting from, among others, trauma, infection, or tumor resection often do not heal spontaneously, and require surgical intervention. In addition, the treatment

\footnotetext{
* Correspondence: e.vanlieshout@erasmusmc.nl

'Department of Surgery-Traumatology, Erasmus MC, University Medical Centre Rotterdam, P.O. Box 2040, 3000 CA Rotterdam, the Netherlands Full list of author information is available at the end of the article
}

of posttraumatic skeletal complications such as delayed unions, nonunions, or malunions frequently require bone grafting. Variations in size or location of the defect, but also patient related factors such as age and disease status determine the therapeutic approach. Herein, bone grafts provide support, fill voids, and enhance the biological repair of the defect.

Autogenous bone, either cortical or cancellous, harvested from the patient's iliac crest is considered the gold standard graft. Autogenous bone is an excellent grafting material, since it provides three of the four critical elements for bone repair; an osteoconductive matrix that provides a scaffold for bone ingrowth, growth factors that stimulate osteoinduction, and living bone cells that offer osteogenesis [5]. However, as the cells do not necessarily survive transplantation, the clinical benefit is not guaranteed per se [6]. Several limitations have been
C Biomed Central

2011 Van Lieshout et al; licensee BioMed Central Ltd. This is an Open Access article distributed under the terms of the Creative Commons Attribution License (http://creativecommons.org/licenses/by/2.0), which permits unrestricted use, distribution, and reproduction in any medium, provided the original work is properly cited. 
noted, including a limited amount or inappropriate shape of the graft [1]. Also, the harvesting of autogenous bone tissue lengthens the surgical procedure, and is associated with an $8-39 \%$ risk of complications that include infection, blood loss, haematoma, nerve and urethral injury, fracture, pelvic instability, cosmetic disadvantages, postoperative pain, and morbidity and chronic pain at the donor site [1,7-14]. Finally, the use of autografts is not recommended in elderly or pediatric patients or in patients with a malignancy or infectious disease.

Alternative bone grafts like iso-, allo-, and xeno-transplants have been applied, but due to (major) disadvantages their use is discouraged (for review, see $[1,8]$ ).

The first use of plaster of paris (gypsum) as an artifical bone substitute was reported on in 1892 [15]. Technological evolution and a better understanding of bone-healing biology have led to the development of alternative (synthetic) bone substitutes. In the eighties, calcium phosphate salts such as tricalciumphosphate (TCP) and hydroxyapatite (HA) were introduced for clinical use [16]. Although they do not exist naturally, TCP and HA have been shown to induce a biologic response similar to that of bone [1]. Other groups of compounds available are calcium sulphate (gypsum), type I collagen and non-biologic substrates like degradable polymers and bioactive glass $[1,17,18]$. Over 20 bone substitute products are registered at present for use in orthopaedic trauma surgery in the Netherlands [19]. They differ in composition, characteristics, appearances, and delivery forms (e.g., pastes, solid matrices, or granules).

Availability of an increasing number of products may seem attractive; however, without sufficient knowledge on their properties and behavior in vivo it will become more and more complicated to select the product that mimics the bone to be replaced the best. Determining which product to use is based upon many factors including the size and location of the defect as well as the handling properties and ability to deliver the material to the surgical site. The structure and biomechanical characteristics of the products are critical to their success. For the majority of products, these data are mostly lacking. The aim of this study was to investigate the in vitro porosity, structure characteristics, and compression strength and stiffness of bone substitutes that were registered for use in orthopaedic trauma surgery in the Netherlands and were available as (injectable) paste. Standardized tests were performed.

\section{Methods}

\section{Sample preparation}

Nine bone substitutes that were available as (injectable) paste were selected for biomechanical testing; seven calcium phosphate cements, one calcium sulphate and one
Table 1 Bone substitutes tested for their biomechanical characteristics

\begin{tabular}{lll}
\hline Main ingredient & Product name & Producer \\
\hline Calcium phosphate & BoneSource $^{\circledR}$ & Stryker Nederland B.V. \\
& Calcibon $^{\circledR}$ & Biomet Europe \\
& ChronOS $^{\circledR}$ Inject & Synthes, Inc \\
& Eurobone $^{\circledR}$ & Surgical concepts \\
& HydroSet & Stryker Nederland B.V. \\
& Norian SRS & Synthes, Inc \\
& Ostim $^{\circledR}$ & Hereaus \\
Calcium sulphate & MIIG $^{\circledR}$ X3 & Wright Medical, Inc \\
Bioactive glass & Cortoss $^{\circledR}$ & Orthovita, Inc \\
\hline
\end{tabular}

bioactive glass (Table 1). The products were stored at room temperature until use. Ten to 12 cylindrical test samples were prepared per product using a custommade Teflon mould (Dept. Experimental Medical Instrumentation, Erasmus MC, Rotterdam, the Netherlands; Figure 1). Samples had a length of $8 \mathrm{~mm}$ and a diameter of $4 \mathrm{~mm}$. This 2:1 ratio was the optimal ratio according Hing et al [20]. Samples were allowed to harden for 20 minutes at room temperature, after which micro-CT scanning was performed. Sample density was calculated from the length, diameter and weight. Subsequently, samples were kept at $37^{\circ} \mathrm{C}$ for 3 days in sterile water to allow for maximal hardening, upon which a compression test was performed.

\section{Micro-CT scanning}

Architecture was determined using a micro-CT (Skyscan 1076, Kontich, Belgium). The micro-CT was tuned at 70 $\mathrm{kV}$ and $140 \mu \mathrm{A}$, with a resolution of $9 \mu \mathrm{m}$. This setup was verified by scanning a Vitoss ${ }^{\circledR}$ test sample with a known porosity between 88 and 92\% [21], which was indeed within this range (data not shown). CT shadow projection images were converted into a three dimensional reconstruction of cross-sectional images in bitmap files using the volumetric reconstruction software (Nrecon software, Skyscan, Belgium). Total, closed and open porosity, connectivity density, structure model

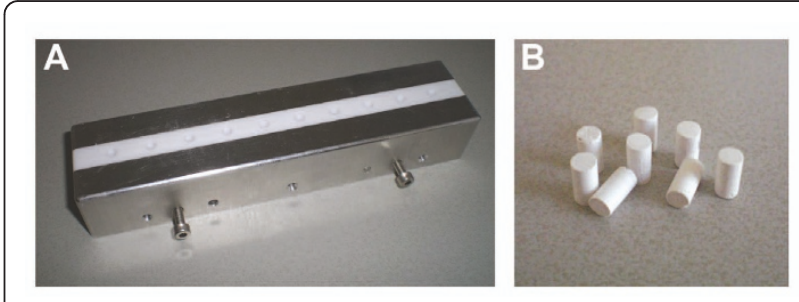

Figure 1 Production of test samples Test samples with a height of $8 \mathrm{~mm}$ and a diameter of $4 \mathrm{~mm}$ were made using a custommade Teflon mold (panel A). Panel B shows examples of Calcibon ${ }^{\circledR}$ test samples. 
index (SMI) and pore size were calculated from these $3 \mathrm{D}$ reconstruction using the CTAn software (SkyScan, Kontich, Belgium). Total porosity was defined as the volume of all open plus closed pores as a percent of the total Volume Of Interest (VOI) volume. Closed porosity represents the volume of the closed pores as a percent of the total of solid plus closed pore volume within the VOI. Open porosity is defined as the volume of open pores as a percent of the total VOI volume. Connectivity density is the number of redundant connections between trabecular structures per unit volume. The SMI indicates the relative prevalence of rods and plates in a $3 \mathrm{D}$ structure. Pore size was defined as the average thickness of the pores, similar to the definition of trabecular spacing and thickness [22].

\section{Biomechanical testing}

The compression strength was determined using unconfined compression tests. Upon five consecutive nondestructive preconditioning cycles, samples were compressed at a velocity of $0.5 \mathrm{~mm} / \mathrm{min}$ to fracture using a standard compression-testing device (Lloyd Instruments, Fareham, UK). The resulting Extension-force curves were converted to Strain-stress curves using formulas I and II:

(I) Strain $(\mathrm{mm} / \mathrm{mm})=$ Extension $/$ Lo

(II) Stress $(\mathrm{MPa})=$ Force $/$ Ao

Herein, Lo is the original length of the sample and Ao is area of the sample. The ultimate strength $(\mathrm{MPa})$ was determined as the maximum force applied per square $\mathrm{mm}$ recorded during the experiment. Stiffness (Young's modulus; $\mathrm{MPa}$ ) was determined as the slope of the linear fit detected during the test.

\section{Data analyses}

Statistical analyses were performed using the Statistical Package for the Social Sciences (SPSS) version 16.0 (SPSS, Chicago, IL, USA). First, a One-Way Analysis of Variance (ANOVA) was performed to test the hypothesis that the mean value for a given parameter was equal for all products. Subsequently, post hoc pairwise multiple comparisons were performed using the Student's T-test, with Bonferroni correction for multiple testing. P-values $<0.05$ were considered statistically significant.

\section{Results}

\section{Sample characteristics}

The average length and diameter were measured in order to check whether the test samples size was as intended. Results are shown in Table 2. The length ranged from $7.694 \pm 0.104 \mathrm{~mm}($ mean $\pm \mathrm{SD})$ for Ostim ${ }^{\circledR}$ to
Table 2 Average length, diameter and weight of the test samples

\begin{tabular}{lcccc}
\hline & N & Length $(\mathbf{m m})$ & Diameter $(\mathbf{m m})$ & Weight $(\mathbf{m g})$ \\
\hline BoneSource $^{\circledR}$ & 10 & $8.225 \pm 0.052$ & $3.980 \pm 0.035$ & $181.8 \pm 6.1$ \\
Calcibon $^{\circledR}$ & 12 & $8.271 \pm 0.045$ & $3.992 \pm 0.047$ & $179.5 \pm 6.1$ \\
ChronOS $^{\circledR}$ & 10 & $8.265 \pm 0.147$ & $3.970 \pm 0.059$ & $174.5 \pm 9.3$ \\
Eurobone $^{\circledR}$ & 10 & $8.365 \pm 0.085$ & $3.985 \pm 0.053$ & $186.5 \pm 5.7$ \\
HydroSet $^{\mathrm{TM}}$ & 10 & $8.325 \pm 0.079$ & $3.970 \pm 0.042$ & $179.8 \pm 13.0$ \\
Norian SRS $^{\circledR}$ & 10 & $8.180 \pm 0.079$ & $3.915 \pm 0.034$ & $171.9 \pm 2.6$ \\
Ostim $^{\circledR}$ & $9^{*}$ & $7.694 \pm 0.104$ & $3.650 \pm 0.103$ & $103.3 \pm 7.2$ \\
MIIG $^{\circledR}$ X3 & 10 & $8.345 \pm 0.064$ & $3.985 \pm 0.053$ & $199.0 \pm 5.4$ \\
Cortoss $^{\circledR}$ & 10 & $7.979 \pm 0.103$ & $3.854 \pm 0.062$ & $166.4 \pm 4.6$ \\
\hline
\end{tabular}

Samples of bone substitute products were prepared using a custom-made Teflon mold as indicated in the Materials and Methods. The length and diameter were measured in order to confirm the intended size $(8 \mathrm{~mm}$ length and $4 \mathrm{~mm}$ diameter). Data are presented as mean \pm SD.

*, one test sample was discarded due to the presence of air bubbles.

$8.365 \pm 0.085 \mathrm{~mm}$ for Eurobone ${ }^{\circledR}$. The diameter ranged from $3.650 \pm 0.103 \mathrm{~mm}$ for Ostim ${ }^{\circledR}$ to $3.992 \pm 0.047$ for Calcibon ${ }^{\circledR}$. Both the length and diameter of Ostim ${ }^{\circledR}$ were statistically significantly less than the other products, implying that the Ostim ${ }^{\circledR}$ samples had slightly shrunken ( $<$ 0.001, Mann-Whitney U-test).

The average weight of the test samples varied twofold. The lowest recorded mean weight was $103.3 \pm 7.2 \mathrm{mg}$ for Ostim ${ }^{\circledR}$, whereas MIIG $^{\circledR}$ X3 had a weight of $199.0 \pm$ $5.4 \mathrm{mg}$ (Table 2).

The density of all test samples was calculated from the length, diameter and weight (Figure 2). The $\mathrm{CaSO}_{4}$ MIIG $^{\circledR}$ X3 had the highest density $(1.92 \pm 0.08 \mathrm{mg} /$ $\mathrm{mm}^{3}$ ), followed by the bioactive glass Cortoss ${ }^{\mathbb{B}}$ and the $\mathrm{CaPO}_{4}$ Eurobone $^{\circledR}$, which both had an average density of $1.79 \mathrm{mg} / \mathrm{mm}^{3}$. The density of the other $\mathrm{CaPO}_{4}$ products ranged from $1.78 \pm 0.07 \mathrm{mg} / \mathrm{mm}^{3}$ (BoneSource ${ }^{\circledR}$ ) to1.29 $\pm 0.09 \mathrm{mg} / \mathrm{mm}^{3}\left(\right.$ Ostim $\left.^{\circledR}\right)$. The density of MIIG ${ }^{\circledR}$ $\mathrm{X} 3$ was significantly higher than all other products, whereas the density of Ostim ${ }^{\circledR}$ was significantly lower.

\section{Porosity and pore size}

In order to gain insight into the porous structure of the bone substitute materials, the porosity and pore sizes were calculated from micro-CT images. Ostim ${ }^{\circledR}$ was the only product that had a clear porous structure. The total porosity $(52.66 \pm 10.14 \%)$ was significantly higher than the porosity of all other products (Figure 3A). The porosity of the other products diminished from $6.93 \pm$ $1.32 \%\left(\right.$ ChronOS $^{\circledR}$ ) to $0.48 \pm 0.15 \%$ for Norian SRS $^{\circledR}$. As total porosity is dictated by open as well as closed pores, the open porosity and closed porosity were also determined. Open porosity was evident for Ostim ${ }^{\circledR}$ $(50.52 \pm 4.49 \%$; Figure 3B), and diminished from $2.86 \pm$ $0.92 \%\left(\right.$ ChronOS $^{\mathbb{B}}$ ) to $0.22 \pm 0.75 \%$ for Calcibon ${ }^{\circledR}$. Closed porosity exceeded was highest for ChronOS $^{\circledR}$ 


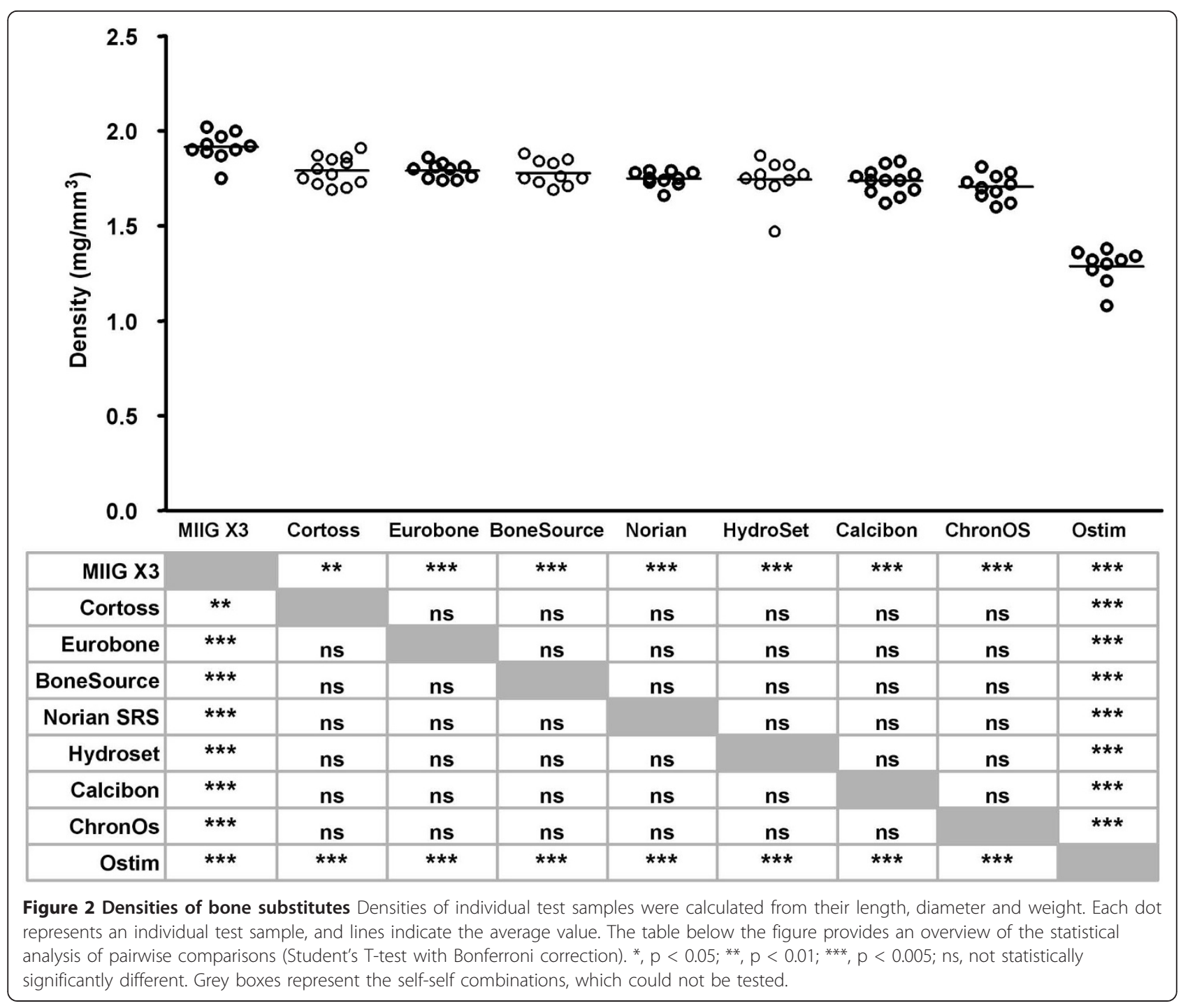

$(3.59 \pm 0.41 \%)$ and HydroSet ${ }^{\mathrm{TM}}(2.66 \pm 0.49 \%)$, and lowest for Ostim ${ }^{\circledR}(0.43 \pm 0.32 \%)$, Norian SRS ${ }^{\circledR}(0.33 \pm$ $0.13 \%)$, and $\mathrm{MIIG}^{\circledR} \mathrm{X} 3(0.29 \pm 0.07 \%$; Figure $3 \mathrm{C})$.

The porous structure of the bone substitute materials is determined by their porosity and pore size. Only two products had a mean pore size that exceeded $100 \mu \mathrm{m}, i$. e., $162.2 \pm 107.1 \mu \mathrm{m}$ for Eurobone ${ }^{\circledR}$ and 148.4 \pm 70.6 $\mu \mathrm{m}$ for Cortoss $^{\circledR}$ (Figure 4). Pore sizes of Norian SRS ${ }^{\circledR}$ $(47.2 \pm 21.9 \mu \mathrm{m})$, Calcibon ${ }^{\circledR}(41.6 \pm 22.0 \mu \mathrm{m})$ and BoneSource $^{\circledR}(33.4 \pm 6.2 \mu \mathrm{m})$ were below $50 \mu \mathrm{m}$.

For each product the range in pore sizes is shown in Figures 5. Of all products, BoneSource ${ }^{\circledR}$ had the smallest pores. Over $95 \%$ of pores were smaller than $60 \mu \mathrm{m}$, of which approximately half were $<26.7 \mu \mathrm{m}$. No pores $>$ $100 \mu \mathrm{m}$ were found. This was also seen in Ostim ${ }^{\circledR}$, of which $95 \%$ of pores were smaller than $85 \mu \mathrm{m}$. Calcibon ${ }^{\circledR}$, Norian SRS ${ }^{\circledR}$ and HydroSet ${ }^{\mathrm{TM}}$ incidentally showed pores up to $230 \mu \mathrm{m}$, however $95 \%$ were smaller than $125 \mu \mathrm{m}$.
Of the CaPO4 products, ChronOS ${ }^{\circledR}$ and Eurobone ${ }^{\circledR}$ were the only two that contained pores up to $500 \mu \mathrm{m}$, with $95 \%$ of pores being smaller than $250 \mu \mathrm{m}$ and $330 \mu \mathrm{m}$, respectively. The distribution of pore sizes of the $\mathrm{CaSO}_{4}$ MIIG $^{\circledR}$ X3 appeared similar as that of Norian SRS ${ }^{\circledR}$ and, to a lesser extent, Calcibon ${ }^{\circledR}$. However, with a maximum pore size of $250 \mu \mathrm{m}$ and $90 \%$ of pores being $<190 \mu \mathrm{m}$, pores of MIIG $^{\circledR}$ X3 were relatively larger. The pore size frequency of Cortoss ${ }^{\circledR}$ deviated from that of the other products tested, as a large range of pore sizes (25 to 300 $\mu \mathrm{m})$ were approximately equally present. In this bioactive glass $95 \%$ of pores had sizes up to $390 \mu \mathrm{m}$, although pores of $500 \mu \mathrm{m}$ were also found. Combining the data of total porosity and average pore size implied that bone substitute materials provide a wide range of products. Some had a high porosity with small pores (e.g., Ostim $\left.{ }^{\circledR}\right)$, and at the other side of the spectrum products had a low porosity with large pores (e.g., Eurobone $\left.{ }^{(}\right)$. 

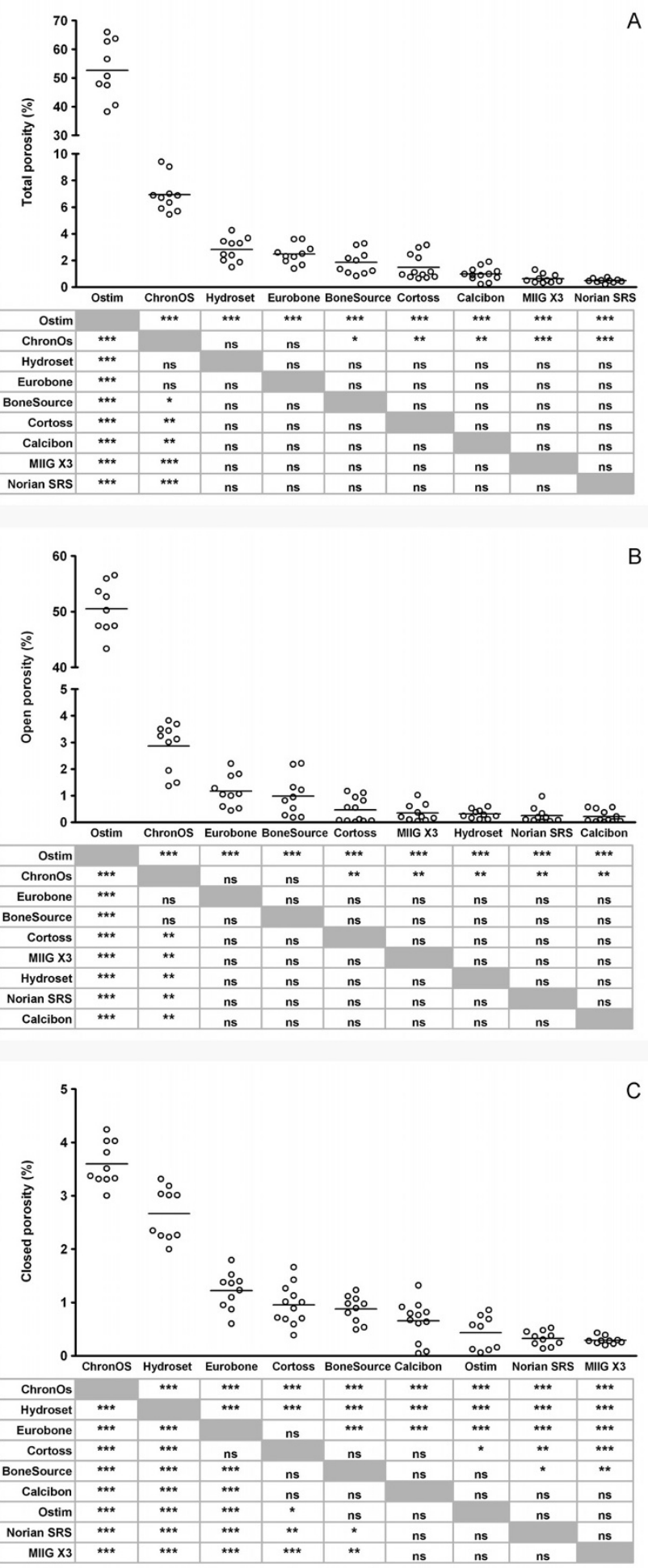

Figure 3 Porosity of bone substitutes Porosity of individual test samples was determined upon Micro-CT-scanning as described in the Materials and Methods. The total porosity (A), open porosity (B) and closed porosity (C) were determined. Each dot represents an individual test sample, and lines indicate the average value. The table below the figure shows the outcome of the pairwise comparisons (Student's T-test with Bonferroni correction). * $p<0.05 ;{ }^{* *}, p<0.01 ;{ }^{* *}, p<0.005 ; n s$, not statistically significantly different. Grey boxes represent the self-self combinations, which could not be tested. 


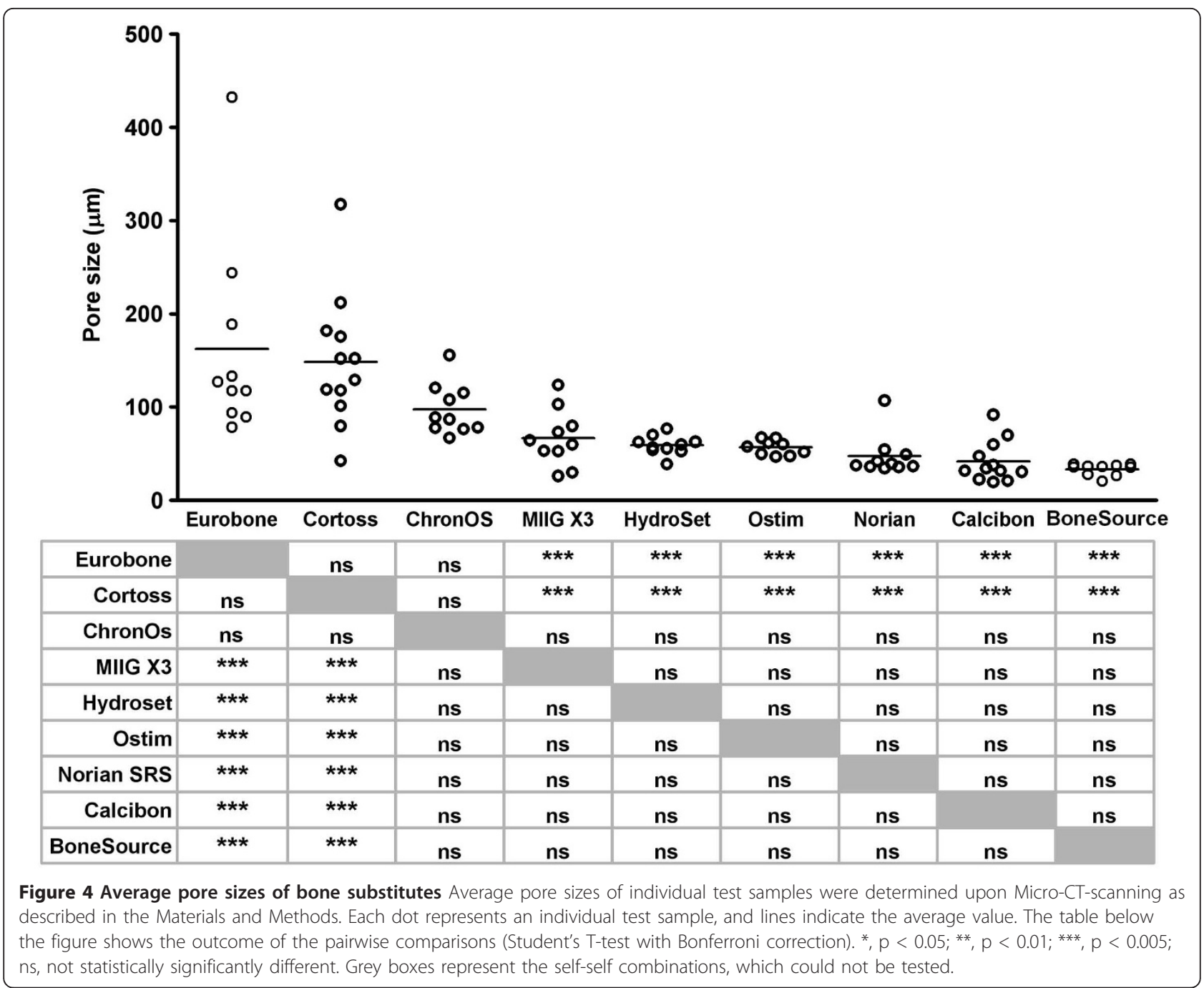

\section{Connectivity density and structure model index}

In order to further characterize the architecture of the bone substitutes, their connectivity density and structure model index were determined. The connectivity density was $>25 / \mathrm{cm}^{3}$ for HydroSet ${ }^{\mathrm{TM}}\left(27.17 \pm 6.22 / \mathrm{cm}^{3}\right)$, and between 5 and 10 for Norian SRS ${ }^{\circledR}$, MIIG $^{\circledR}$ X3, and $\operatorname{Ostim}^{\circledR}\left(8.77 \pm 2.81,5.87 \pm 2.32\right.$, and $5.80 \pm 0.84 / \mathrm{cm}^{3}$, respectively; Figure 6).

Ostim ${ }^{\circledR}$ was the only product with a positive structure model index (SMI) $(0.125 \pm 1.165$; Figure 7$)$. For the other products, the SMI declined from -37.715 \pm 7.280 for ChronOS $^{\circledR}$ and $-67.752 \pm 8.913$ for HydroSet ${ }^{\mathrm{TM}}$ to $-123.717 \pm 38.232$ for Cortoss ${ }^{\circledR}$.

\section{Compression strength and Young's modulus}

The compression strength of all products was determined using unconfined compression tests. Cortoss ${ }^{\circledR}$ had the highest ultimate compression strength (47.32 \pm 20.34 MPa; see Figure 8). This was statistically significantly higher than the strength of all other products. Next in order of diminishing strength were Calcibon $^{\circledR}$ and Norian SRS ${ }^{\circledR}(33.95 \pm 6.75$ and 25.64 \pm 7.37 $\mathrm{MPa}$, respectively), which was statistically significantly higher than most other products. ChronOS ${ }^{\circledR}$ and Ostim ${ }^{\circledR}$ had poor compression strengths $(0.81 \pm 0.32$ and $0.24 \pm 0.05 \mathrm{MPa}$, respectively).

Calcibon $\left.^{(}\right)$had the highest Young's modulus $(790 \pm 132$ $\mathrm{MPa}$; Figure 9), followed by Norian SRS ${ }^{\circledR}$ and MIIG ${ }^{\circledR}$ X3 $(674 \pm 146 \mathrm{MPa}$ and $665 \pm 154 \mathrm{MPa}$, respectively). The Young's modulus of these three products was statistically significantly higher than that of the other products. ChronOS $^{\circledR}$ and Ostim ${ }^{\circledR}$ had a very low Young's modulus $(54 \pm 20 \mathrm{MPa}$ and $6 \pm 3 \mathrm{MPa}$, respectively), which was statistically significantly lower than all other products.

\section{Discussion}

Osteoconductive porous biomaterials provide a scaffold for the ingrowth of bone. With respect to pore size, 


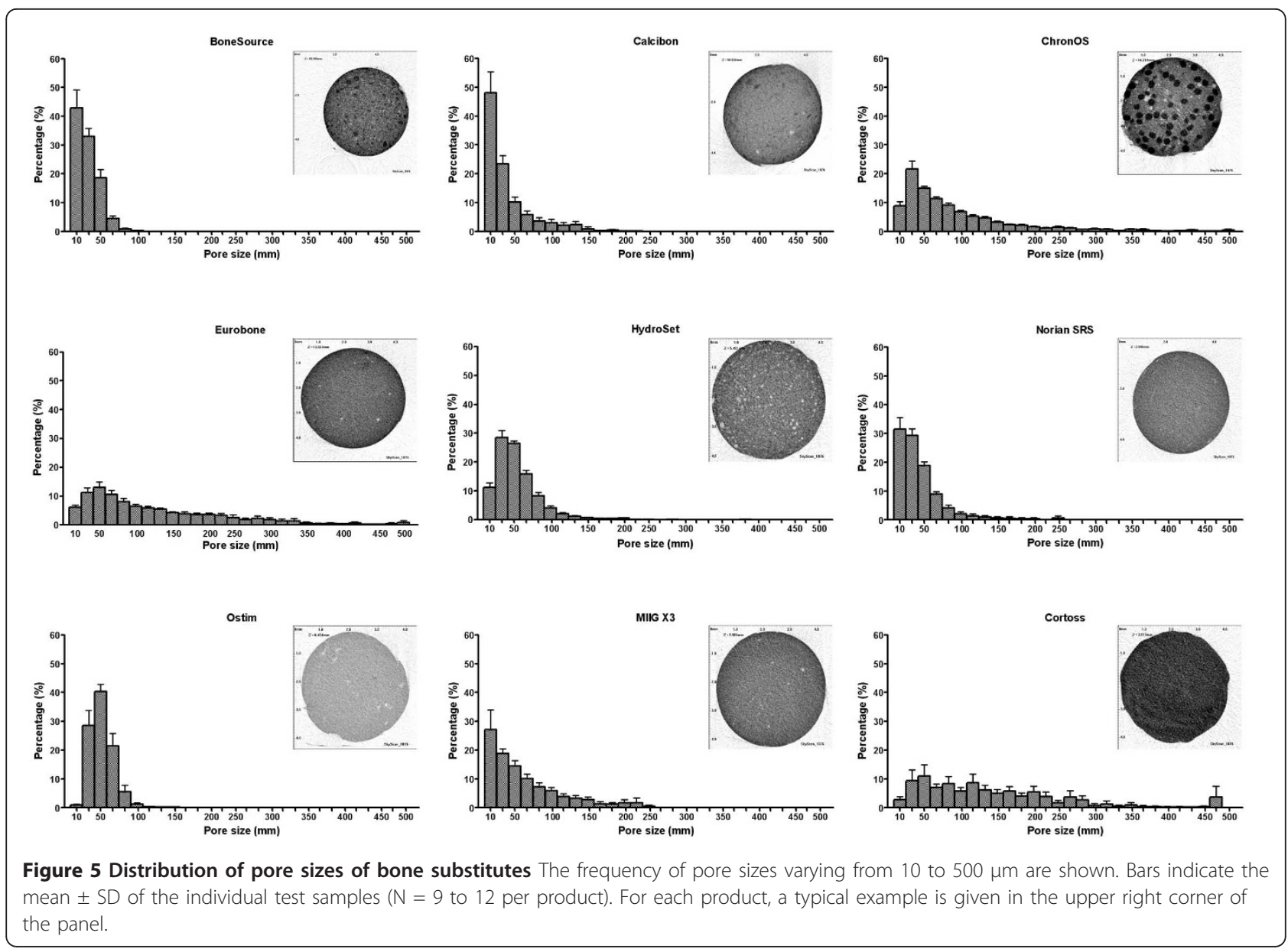

microporosity (i.e., pores with a size $<5 \mu \mathrm{m}$ ) is considered important for the bioresorbability of the material [23], whereas macroporosity (i.e., pores $>100 \mu \mathrm{m}$ ) plays an important role in the osteoconductivity. A large macroporosity (i.e., 400-600 $\mu \mathrm{m}$ ) facilitates infiltration by fibrovascular tissue and revascularization, thereby allowing for bone reconstruction. Investigations of bone ingrowth into porous materials with varying pore size have led to the consensus that the optimal pore radius for bone ingrowth is $>50 \mu \mathrm{m}$ and perhaps as large as $150 \mu \mathrm{m}$ [24-27]. Of the bone substitute materials tested, Eurobone $^{\circledR}$, Cortoss $^{\circledR}$, and ChronOS ${ }^{\circledR}$ could be considered as truly osteoconductive in terms of pore size, as they contain a considerable number of pores with sizes of up to $500 \mu \mathrm{m}$. For ChronOS $^{\circledR}$ the presence of pore sizes between 100 and $400 \mu \mathrm{m}$ have been shown before $[28,29]$. Pore sizes between $100-250 \mu \mathrm{m}$ are only marginally present in Calcibon ${ }^{\circledR}$, HydroSet $^{\mathrm{TM}}, \mathrm{MIIG}^{\circledR} \mathrm{X} 3$, and Norian SRS ${ }^{\circledR}$. BoneSource ${ }^{\mathbb{B}}$ and Ostim ${ }^{\circledR}$ do not contain pores with a size of at least $100 \mu \mathrm{m}$, so based upon this in vitro measurement, these might not be considered as highly osteoconductive based upon pore size alone. This is in agreement with literature data available for BoneSource ${ }^{\circledR}(2-50 \mu \mathrm{m})$ [30] and Calcibon ${ }^{\circledR}$ $(<1 \mu \mathrm{m})$ [31].

The invasion by host tissue is mostly facilitated by a larger porosity. Of the products tested, Ostim ${ }^{\circledR}$ is the only product with a high mean total porosity of approximately $53 \%$. Porosity of all other products is below $7 \%$, with Norian SRS ${ }^{\circledR}$ being the densest $(0.48 \%$ mean total porosity). The total porosity as found for Cortoss ${ }^{\circledR}$ (1.48 $\pm 0.94 \%)$ is in line with the $1 \%$ mentioned by the supplier. It is unclear why porosities of some other products were lower than previously published data, indicating a porosity of $60-75 \%$ ) for ChronOS $^{\circledR}$ [28,29], $46 \%$ for BoneSource ${ }^{\circledR}[32,33]$, and $30-40 \%$ for Calcibon ${ }^{\circledR}[31,34]$. This difference is unlikely to be due to an inadequate test design, since the porosity of $88-92 \%$ as found for the Vitoss ${ }^{\circledR}$ test sample was exactly as previously shown [21]. As pores with a diameter below $9 \mu \mathrm{m}$ could not be detected due to resolution restrictions of the CT scanner used in the present study, it cannot be ruled out that porosity and pore sizes are (slightly) under-estimated or overestimated, respectively. However, this 


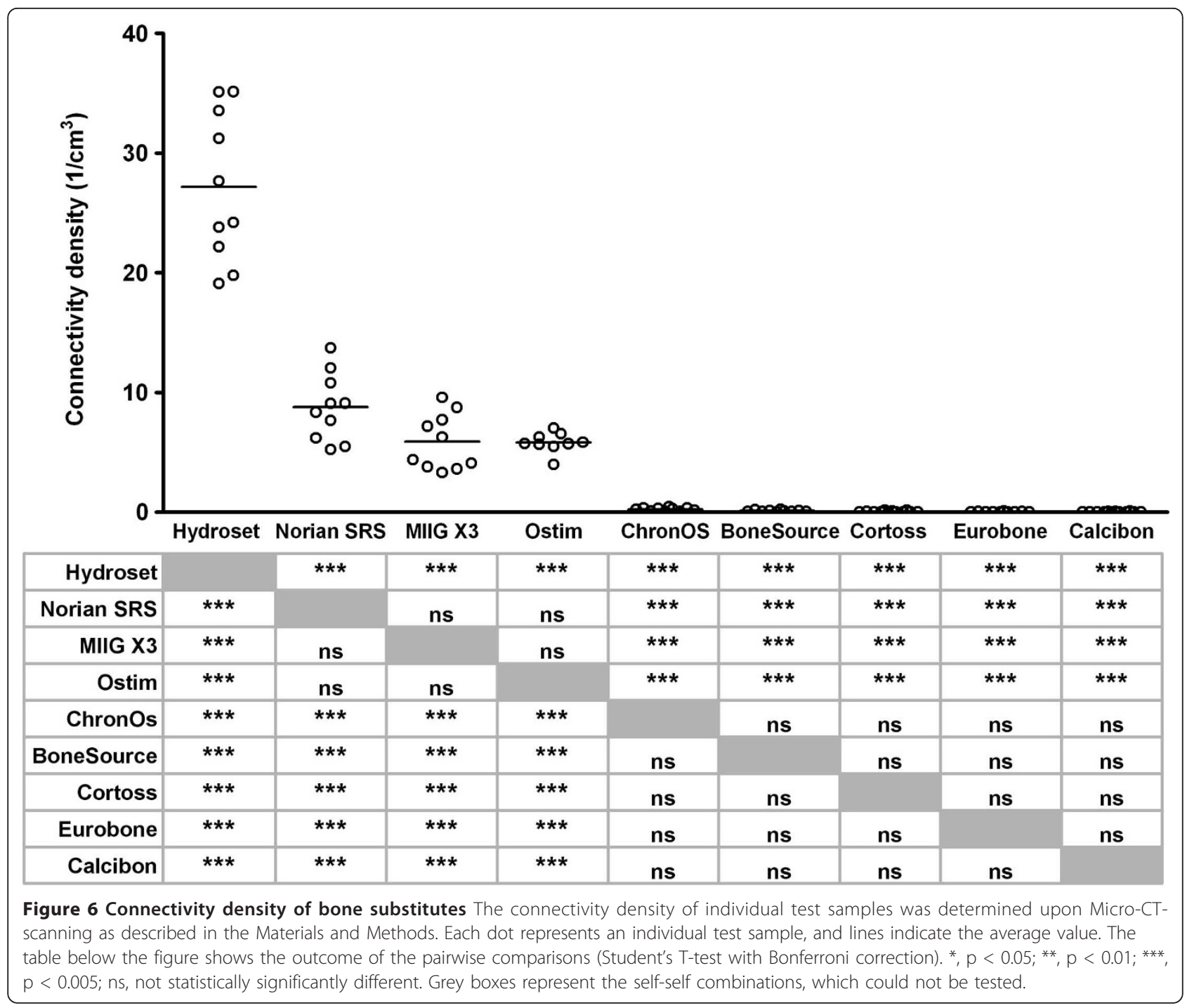

unlikely explains differences between our data and literature data.

Adequate pore volume alone is not sufficient for achieving osteoconduction. Pore connectivity may determine the effectiveness of porosity [20,24,35-42]. In general, biomaterials with interconnected pores are considered to be superior to biomaterials containing closed pores, as interconnecting fenestrations provide the space for vascular tissue required for continued ingrowth of mineralized bone $[27,35,36]$. White \& Shors indicated that such pore interconnections must be larger than $100 \mu \mathrm{m}$ [37]. Of the products tested in this study, HydroSet $^{\mathrm{TM}}$, Norian SRS ${ }^{\circledR}, \mathrm{MIIG}^{\circledR} \mathrm{X} 3$, and Ostim ${ }^{\circledR}$ had more than five interconnected pores per $\mathrm{cm}^{3}$. Connectivity density of the other products was $0.23 / \mathrm{cm}^{3}$ or less. A negative correlation was found between pore size and connectivity density (Pearson correlation, $r_{p}=-0.21, p=$
0.043), indicating that products with a lower pore size had a higher representation of interconnected pores.

The structure model index (SMI) indicates the relative prevalence of rods and plates in a $3 \mathrm{D}$ structure. SMI involves a measurement of surface convexity. Concave surfaces of enclosed cavities represent negative convexity to the SMI parameter. SMI values of ideal plates, cylinders and spheres are 0,3 , and 4 , respectively. With a mean SMI value $<0.2$ Ostim ${ }^{\circledR}$ appears to be mainly composed of plates. It is known that products with a total porosity below $50 \%$ often have a negative SMI. In this study, that was the case for eight out of nine products. Overall, SMI is positively correlated with total porosity, open porosity, and closed porosity $\left(r_{p}=0.672\right.$, 0.645 and 0.358 , respectively; $\mathrm{p}<0.001$ ), and negatively with compression strength and Young's Modulus $\left(\mathrm{r}_{\mathrm{p}}=\right.$ -0.679 and -0.638 , respectively, $\mathrm{p}<0.001$ ). 


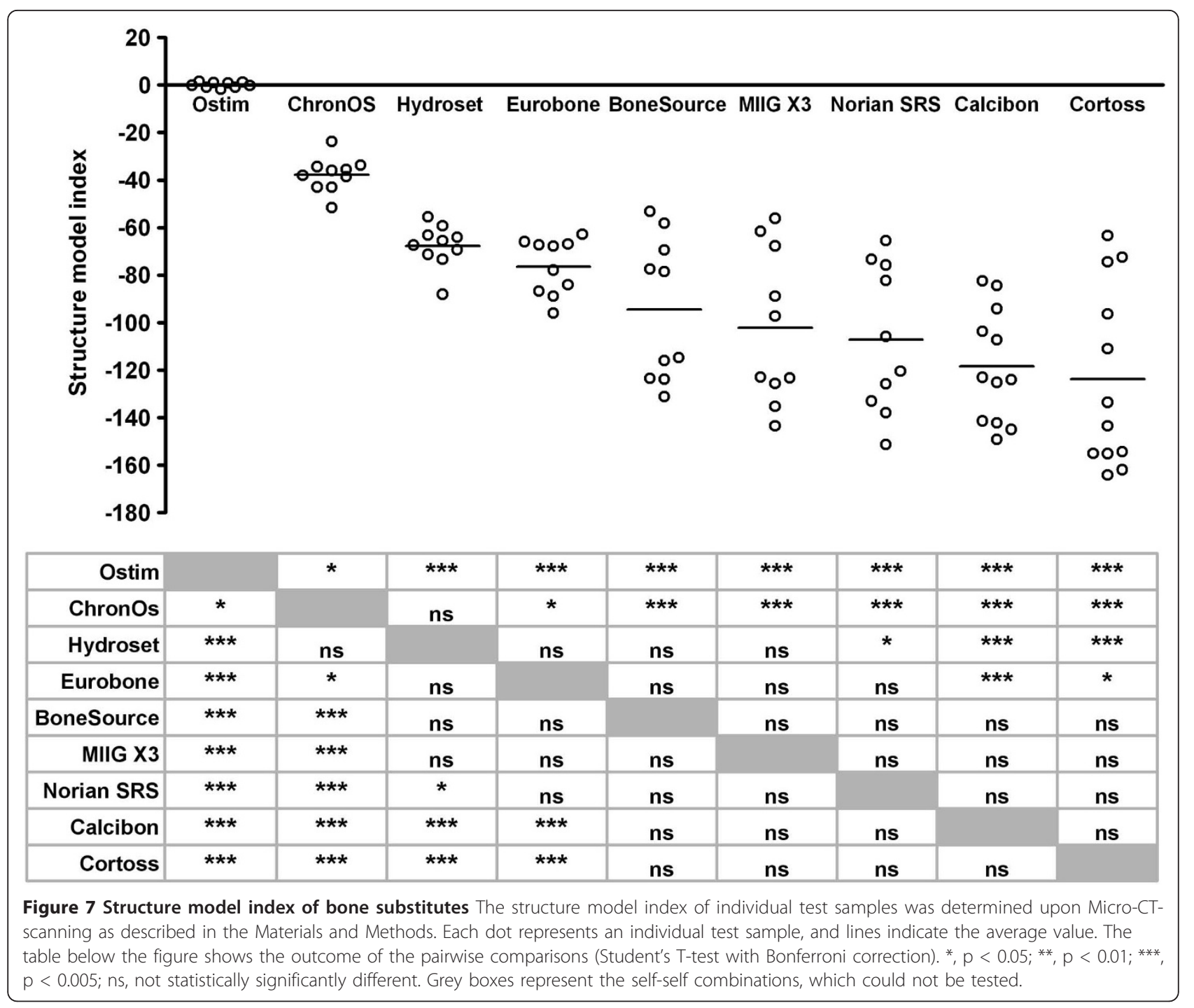

Although faster ingrowth is favoured by a more porous and interconnected structure, denser ceramics have better mechanical integrity $[20,24,27]$. For example, an increase of the total porous volume from $10 \%$ to $20 \%$ can result in a four-fold decrease in mechanical strength $[27,43,44]$. Of the bone substitute products tested, this phenomenon is most pronounced for Ostim ${ }^{\mathbb{B}}$. Ostim ${ }^{\circledR}$ has the highest total porosity (mean $~ 53 \%$ ), but has poor compressive strength (mean $0.24 \mathrm{MPa}$ ) and Young's modulus $(6 \mathrm{MPa})$. Calcibon ${ }^{\circledR}$ and Norian SRS ${ }^{\circledR}$, on the other hand, have low porosity $(0.93 \%$ and $0.48 \%$, respectively), but display a relatively high compressive strength (33.9 $\mathrm{MPa}$ and $25.6 \mathrm{MPa}$, respectively). Our data are in line with previous measurements, which revealed a compression strength of 6.3-34 $\mathrm{MPa}$ for BoneSource $^{\circledR}[45,46], 35-55 \mathrm{MPa}$ for Calcibon ${ }^{\circledR}[34,47]$, 14-24 MPa for HydroSet ${ }^{\mathrm{TM}}$ [48], and 23-55 MPa for Norian SRS $^{\circledR}$ [49-51]. For MIIG $^{\circledR} \mathrm{X} 3$, an in vivo compression strength of $0.6 \mathrm{MPa}$ has been shown at 13 weeks follow up in a canine fracture model [52]. This is lower than the $21.82 \pm 21.93 \mathrm{MPa}$ found in the current in vitro study, and is most likely due to a high degree of biodegradation and resorption of the $\mathrm{MIIG}^{\mathbb{B}} \mathrm{X} 3$ graft, as calcium sulphates are generally resorbed within 8-10 weeks. The 91-179 MPa as published for Cortoss ${ }^{\mathbb{B}}$ [53] is higher than we found. This may be due to the larger size of the test samples (i.e., $8 \times 7.5 \times 100 \mathrm{~mm}$ ) in the study by Boyd et al. [53]. As size and shape of the tested samples as well as the test setup itself may influence the outcome of the compression test, our data may allow for a more objective comparison of strengths between the products.

Overall, compression strength was negatively correlated with total porosity $\left(r_{p}=-0.424, p<0.001\right)$, open porosity $\left(\mathrm{r}_{\mathrm{p}}=-0.399, \mathrm{p}<0.001\right)$, closed porosity $\left(\mathrm{r}_{\mathrm{p}}=\right.$ $-0.412, p<0.001)$, and connectivity density $\left(r_{p}=-0.220\right.$, 


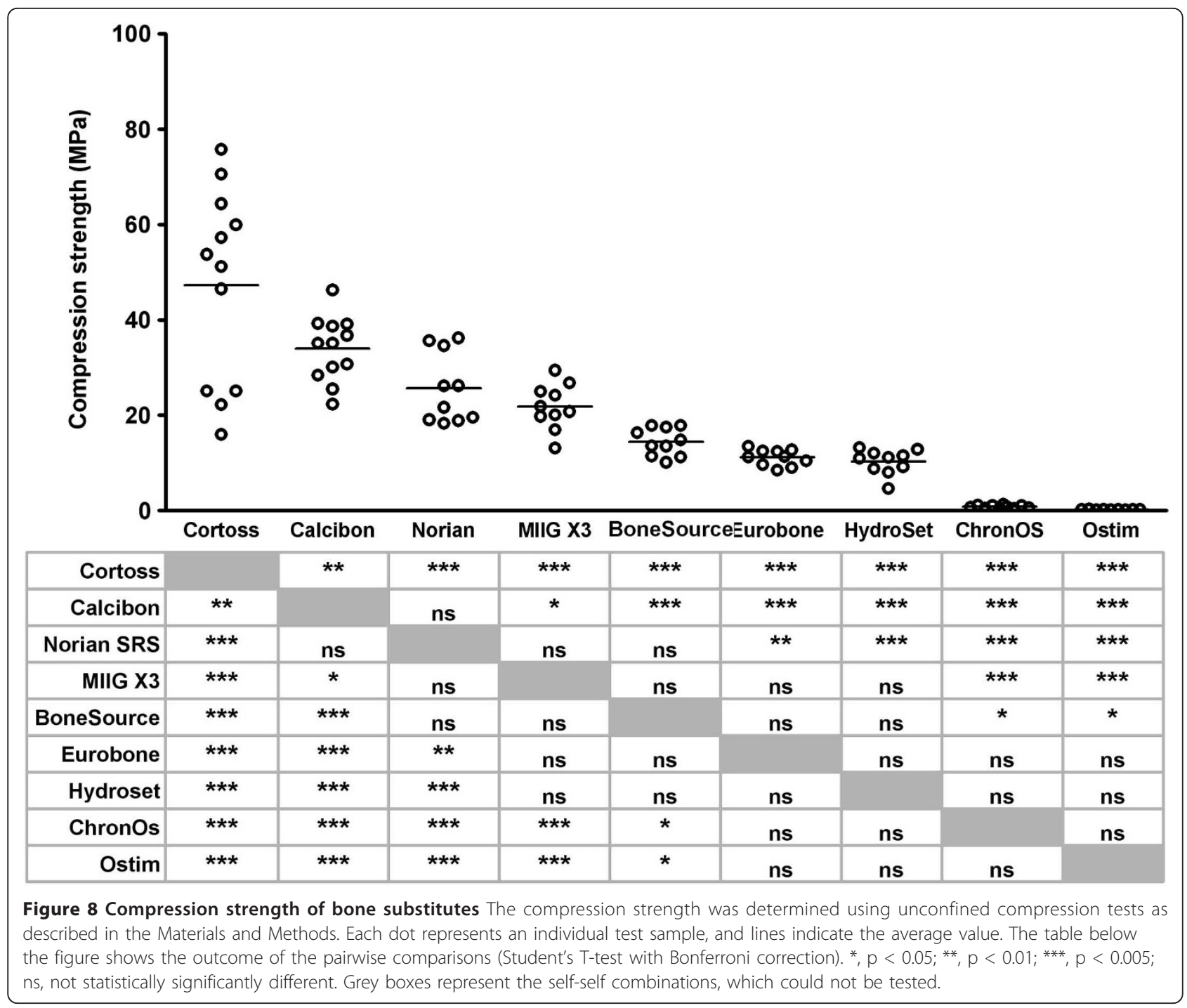

$\mathrm{p}=0.034$ ) (data not shown). Likewise, Young's modulus was negatively correlated with total, open and closed porosity $\left(r_{p}=-0.573,-0.539\right.$ and -0.491 , respectively, $\mathrm{p}<$ 0.001). As opposed to porosity, pore size was unrelated to the compression strength $\left(r_{p}=0.113, p=0.281\right)$ or the Young's modulus $\left(r_{p}=-0.204, p=0.050\right.$; data not shown).

The compounds tested in the current study represent the major classes of artificial bone grafts, i.e., calcium phosphates, calcium sulphate, and bioactive glass. Although selected based upon their availability in the Netherlands, their wide availability makes the data presented in this study generally relevant to most countries. Synthetic calcium phosphate cements can be moulded to irregularly shaped defects, or even injected via syringe before they harden in situ. The two main forms of calcium phosphates currently used are beta-tricalcium phosphate $(\beta-\mathrm{TCP})$ and hydroxyapatite $(\mathrm{HA})$, which can be used separately or combined in composite cements. Due to a general lack of macroporosity calcium phosphate cement degrades layer by layer from the outside to the inside. HA-cements tested include such as Ostim ${ }^{\circledR}$ and HydroSet ${ }^{\circledR}$ have a limited resorption rate. They are characterized by a high porosity, but a relatively low compressive strength. Clinical indications for Ostim $^{\circledR}$ include fractures of the tibia plateau [54,55], calcaneus [54], and distal radius [54,56,57]. There are currently no publications on clinical use of HydroSet ${ }^{\mathrm{TM}}$.

$\beta$-TCP has a compressive strength similar to that of cancellous bone [58], which may allow earlier weight bearing. However, it has a relatively high resorption rate. The $\beta$-TCPs ChronOs ${ }^{\mathrm{TM}}$ is mostly used in vertebral augmentation [59].

Combining HA and $\beta$-TCP improves the porosity of HA cement paste following implantation, because macropores are introduced into the $\mathrm{HA}$ composite after passive 


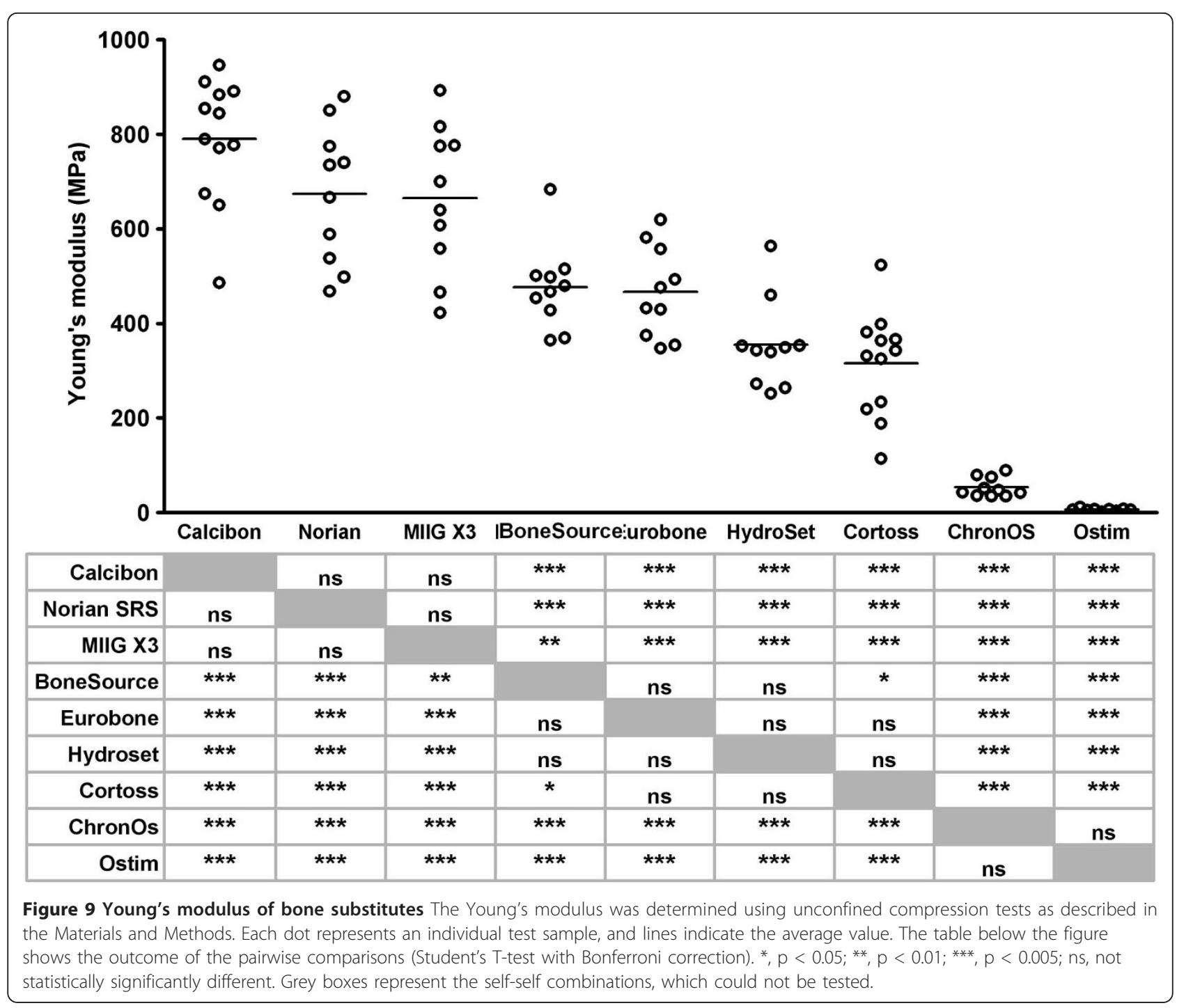

resorption of the $\beta$-TCP component. Subsequently, active resorption by monocytes/macrophages and osteoclasts can take place. Overall, calcium phosphate cement offers the highest mechanical compressive strength of any of the osteoconductive bone graft substitutes. Products such as BoneSource $^{\circledR}$, Calcibon $^{\circledR}$, ChronOs $^{\circledR}$ Inject, HydroSet ${ }^{\mathrm{TM}}$, and Norian SRS $^{\circledR}$ are densely packed at first, but will develop a porous network following resorption of the $\beta$-TCP component. Norian SRS ${ }^{\circledR}$ and BoneSource ${ }^{\circledR}$ have been studied the most; their clinical indications include fractures of the femur [60-63], tibia plateau [60,64,65], calcaneus $[60,66,67]$, humerus $[60,68]$, and distal radius $[60,69-72]$. Calcibon ${ }^{\circledR}$ is mostly used in vertebral augmentation [73-75]. There are currently no publications on the clinical use of Eurobone ${ }^{\circledR}$.

Of the available osteoconductive bone graft substitutes, calcium sulphate is the most rapidly resorbed. Because of its rapid resorption rate and low mechanical strength, calcium sulphate is recommended as a bone graft extender rather than as void filler. Clinical indications of MIIG $^{\circledR}$ X3 include fractures of the distal tibia and tibia plateau [76,77].

Bioactive glass possesses superior mechanical strength compared with calcium phosphate products, as a result of strong graft-bone bonding [1]. It is mainly used in craniofacial reconstructive surgery, dental, and orthopaedic trauma surgery. Cortoss ${ }^{\circledR}$ is a low-viscosity glass-based cement that has been used successfully in fractures of the distal radius [78] and in vertebral augmentation [79,80].

The current study is restricted to biomechanical testing of bone substitute materials in vitro. As a next step, the biological behavior of these products in vivo should be determined in a standardized, comparative study. Pastes may harden less quickly in an aqueous dispersion in vivo, which may affect it ultimate strength. Combining data of our previous systematic review [19] with the 
data of the current in vitro study and a future in vivo study will allow for the development of a clinical guideline.

\section{Conclusions}

The nine bone substitutes studied each have their individual characteristics, and provide orthopaedic trauma surgeons with a choice of products that varies largely in architecture and strength. Only for Eurobone ${ }^{\circledR}$ and Cortoss ${ }^{\circledR}$ the pore sizes exceed the $100 \mu \mathrm{m}$ that is regarded necessary for proper osteoconduction. Biological and biomechanical characteristics of bone substitutes determine their applicability and success rate. Therefore, the in vivo behavior of these compounds (e.g., resorption rate and quality in bone ingrowth) should be taken into account as well. In general, bioactive glass will not resorb, and HA cements will remain in place for years. On the other hand, calcium sulphate cements may disappear before bone ingrowth has taken place. Calcium phosphate cements are generally densely packed and, consequently, provide more mechanical strength. The data outlined here will assist surgeons in selecting the most suitable product for specific clinical indications. Further studies on their in vivo behavior are needed for developing clinical guidelines for use of alternative bone substitute materials in orthopaedic trauma surgery.

\section{Acknowledgements}

Mr. Sander Botter (Erasmus MC, Dept. of Orthopaedics, Rotterdam, the Netherlands) is greatly acknowledged for his assistance in micro-CT scanning. The authors would also like to thank the following companies for donating bone substitute materials: Biomet Nederland B.V. $\left(\right.$ Calcibon ${ }^{\circledR}$ ), Hereaus $\left(\right.$ Ostim $\left.{ }^{\circledR}\right)$, Orthovita (Cortoss ${ }^{\circledR}$ ), Stryker Nederland B.V. (BoneSource ${ }^{\circledR}$ and HydroSet' $\left.{ }^{\mathrm{TM}}\right)$, Synthes Nederland $\left(\mathrm{ChronOS}^{(\mathbb{R}}\right.$ and Norian SRS $\left.{ }^{\circledR}\right)$, Surgical concepts (Eurobone ${ }^{\circledR}$ ), and Wright Medical (M\|G ${ }^{\circledR}$ X3).

Part of this work was made possible with a grant of the Fonds NutsOhra.

\section{Author details}

'Department of Surgery-Traumatology, Erasmus MC, University Medical Centre Rotterdam, P.O. Box 2040, 3000 CA Rotterdam, the Netherlands. ${ }^{2}$ Orthopedic Research Laboratory, Department of Orthopaedics, Erasmus MC, University Medical Centre Rotterdam, P.O. Box 1738, 3000 DR Rotterdam, the Netherlands.

\section{Authors' contributions}

EMMVL, HW and PP designed the study. GHVK and YEM prepared all test samples and conducted the measurements. GHVK, YEM, and EMMVL extracted micro-CT data. EMMVL performed statistical analysis and designed all Figures and Tables. HW and PP critically revised the manuscript. All authors have read and approved the final manuscript.

\section{Competing interests}

The authors declare that they have no competing interests.

Received: 11 October 2010 Accepted: 2 February 2011

Published: 2 February 2011

\section{References}

1. Giannoudis PV, Dinopoulos H, Tsiridis E: Bone substitutes: an update. Injury 2005, 36(Suppl 3):S20-27.

2. Lewandrowski KU, Gresser JD, Wise DL, Trantol DJ: Bioresorbable bone graft substitutes of different osteoconductivities: a histologic evaluation of osteointegration of poly(propylene glycol-co-fumaric acid)-based cement implants in rats. Biomaterials 2000, 21(8):757-764.

3. Muschler GF, Negami S, Hyodo A, Gaisser D, Easley K, Kambic H: Evaluation of collagen ceramic composite graft materials in a spinal fusion model. Clin Orthop Relat Res 1996, , 328: 250-260.

4. Schnettler R, Markgraf E: Knochenersatzmaterialen und Wachstumsfaktoren. Stuttgart: Thieme 1997.

5. De Long WG Jr, Einhorn TA, Koval K, McKee M, Smith W, Sanders R, Watson T: Bone grafts and bone graft substitutes in orthopaedic trauma surgery. A critical analysis. J Bone Joint Surg Am 2007, 89(3):649-658.

6. Sandhu HS, Grewal HS, Parvataneni $\mathrm{H}$ : Bone grafting for spinal fusion. Orthop Clin North Am 1999, 30(4):685-698.

7. Costantino PD, Friedman CD: Synthetic bone graft substitutes. Otolaryngol Clin North Am 1994, 27(5):1037-1074.

8. Patka P, Haarman HJ, Bakker FC: [Bone transplantation and bone replacement materials]. Ned Tijdschr Geneeskd 1998, 142(16):893-896.

9. Younger EM, Chapman MW: Morbidity at bone graft donor sites. J Orthop Trauma 1989, 3(3):192-195.

10. Banwart JC, Asher MA, Hassanein RS: lliac crest bone graft harvest donor site morbidity. A statistical evaluation. Spine 1995, 20(9):1055-1060.

11. Boone DW: Complications of iliac crest graft and bone grafting alternatives in foot and ankle surgery. Foot Ankle Clin 2003, 8(1):1-14.

12. Grob D: [Problems at the donor site in autologous bone transplantation]. Unfallchirurg 1986, 89(8):339-345.

13. Sasso RC, Williams Jl, Dimasi N, Meyer PR Jr: Postoperative drains at the donor sites of iliac-crest bone grafts. A prospective, randomized study of morbidity at the donor site in patients who had a traumatic injury of the spine. J Bone Joint Surg Am 1998, 80(5):631-635.

14. Laurie SW, Kaban LB, Mulliken JB, Murray JE: Donor-site morbidity after harvesting rib and iliac bone. Plast Reconstr Surg 1984, 73(6):933-938.

15. Dressmann H: Ueber Knochenplombierung bei Hohlenformigen Defekten des Knochens. Beitr Klin Chir 1892, 9:804-810.

16. Patka P: Bone replacement by calcium phosphate ceramics [thesis] Amsterdam; 1984.

17. Bauer TW, Muschler GF: Bone graft materials. An overview of the basic science. Clin Orthop Relat Res 2000, , 371: 10-27.

18. Salgado AJ, Coutinho OP, Reis RL: Bone tissue engineering: state of the art and future trends. Macromol Biosci 2004, 4(8):743-765.

19. Van der Stok J, Van Lieshout EM, El-Massoudi Y, Van Kralingen GH, Patka P. Bone substitutes in the Netherlands - a systematic literature review. Acto Biomater 2011, 7(2):739-750.

20. Hing KA, Best SM, Bonfield W: Characterization of porous hydroxyapatite J Mater Sci Mater Med 1999, 10(3):135-145.

21. Resnick DK: Vitoss bone substitute. Neurosurgery 2002, 50(5):1162-1164.

22. Hildebrand T, Ruegsegger P: A new method for the model independent assessment of thickness in three dimensional images. J Microsc 1997, 185:67-75.

23. Driskell TD, O'Hara MJ, Sheets HD Jr, Greene GW Jr, Natiella JR, Armitage J: Development of ceramic and ceramic composite devices for maxillofacial applications. J Biomed Mater Res 1972, 6(1):345-361.

24. Holmes R, Mooney V, Bucholz R, Tencer A: A coralline hydroxyapatite bone graft substitute. Preliminary report. Clin Orthop Relat Res 1984, , 188: 252-262.

25. Karageorgiou $V$, Kaplan D: Porosity of 3D biomaterial scaffolds and osteogenesis. Biomaterials 2005, 26(27):5474-5491.

26. Hulbert SF, Morrison SJ, Klawitter JJ: Tissue reaction to three ceramics of porous and non-porous structures. J Biomed Mater Res 1972, 6(5):347-374.

27. Blokhuis TJ, Termaat MF, den Boer FC, Patka P, Bakker FC, Haarman HJ: Properties of calcium phosphate ceramics in relation to their in vivo behavior. J Trauma 2000, 48(1):179-186.

28. Hiu-Yan Y, Ling Q, Kwong-Man L, Ming Z, Kwok-Sui L, Chun-yiu CJ: Novel approach for quantification of porosity for biomaterial implants using microcomputed tomography (microCT). J Biomed Mater Res B Appl Biomater 2005, 75(2):234-242.

29. Walsh WR, Vizesi F, Michael D, Auld J, Langdown A, Oliver $R$, Yu Y, Irie $H$, Bruce W: Beta-TCP bone graft substitutes in a bilateral rabbit tibial defect model. Biomaterials 2008, 29(3):266-271.

30. Itthichaisri C, Wiedmann-Al-Ahmad M, Huebner U, Al-Ahmad A, Schoen R, Schmelzeisen R, Gellrich NC: Comparative in vitro study of the proliferation and growth of human osteoblast-like cells on various biomaterials. J Biomed Mater Res A 2007, 82(4):777-787. 
31. Link DP, van den Dolder J, Wolke JG, Jansen JA: The cytocompatibility and early osteogenic characteristics of an injectable calcium phosphate cement. Tissue Eng 2007, 13(3):493-500.

32. Gosain AK, Song L, Riordan P, Amarante MT, Nagy PG, Wilson CR, Toth JM, Ricci JL: A 1-year study of osteoinduction in hydroxyapatite-derived biomaterials in an adult sheep model: part I. Plast Reconstr Surg 2002, 109(2):619-630.

33. Gosain AK, Riordan PA, Song L, Amarante MT, Kalantarian B, Nagy PG, Wilson CR, Toth JM, Mclntyre BL: A 1-year study of hydroxyapatite-derived biomaterials in an adult sheep model: III. Comparison with autogenous bone graft for facial augmentation. Plast Reconstr Surg 2005, 116(4):1044-1052.

34. Habraken WJ, Wolke JG, Mikos AG, Jansen JA: Injectable PLGA microsphere/calcium phosphate cements: physical properties and degradation characteristics. J Biomater Sci Polym Ed 2006, 17(9):1057-1074.

35. Hulbert SF, Young FA, Mathews RS, Klawitter JJ, Talbert CD, Stelling FH: Potential of ceramic materials as permanently implantable skeletal prostheses. J Biomed Mater Res 1970, 4(3):433-456.

36. van Eeden SP, Ripamonti U: Bone differentiation in porous hydroxyapatite in baboons is regulated by the geometry of the substratum: implications for reconstructive craniofacial surgery. Plast Reconstr Surg 1994, 93(5):959-966.

37. White E, Shors EC: Biomaterial aspects of Interpore-200 porous hydroxyapatite. Dent Clin North Am 1986, 30(1):49-67.

38. Hing KA, Best SM, Tanner KE, Bonfield W, Revell PA: Mediation of bone ingrowth in porous hydroxyapatite bone graft substitutes. J Biomed Mater Res A 2004, 68(1):187-200.

39. Kuhne JH, Bartl R, Frisch B, Hammer C, Jansson V, Zimmer M: Bone formation in coralline hydroxyapatite. Effects of pore size studied in rabbits. Acta Orthop Scand 1994, 65(3):246-252.

40. Eggli PS, Muller W, Schenk RK: Porous hydroxyapatite and tricalcium phosphate cylinders with two different pore size ranges implanted in the cancellous bone of rabbits. A comparative histomorphometric and histologic study of bony ingrowth and implant substitution. Clin Orthop Relat Res 1988, , 232: 127-138.

41. Lu JX, Flautre B, Anselme K, Hardouin P, Gallur A, Descamps M, Thierry B: Role of interconnections in porous bioceramics on bone recolonization in vitro and in vivo. J Mater Sci Mater Med 1999, 10(2):111-120.

42. Gauthier O, Bouler JM, Aguado E, Pilet P, Daculsi G: Macroporous biphasic calcium phosphate ceramics: influence of macropore diameter and macroporosity percentage on bone ingrowth. Biomaterials 1998, 19(13):133-139.

43. Le Huec JC, Schaeverbeke T, Clement D, Faber J, Le Rebeller A: Influence of porosity on the mechanical resistance of hydroxyapatite ceramics under compressive stress. Biomaterials 1995, 16(2):113-118.

44. Osborn JF, Newesely $\mathrm{H}$ : The material science of calcium phosphate ceramics. Biomaterials 1980, 1(2):108-111.

45. Nitsch A, Patyk A, Schwartz P, Merten HA: [Influence of different mixing fluids on mechanical and micromorphological in vitro qualities of hydroxyapatite cement]. Mund Kiefer Gesichtschir 2005, 9(2):89-94.

46. Pierce WA, Welch RD: Acute compressive strength of hydroxyapatite cement. Trans Orthopd Res Soc 1997, 22:1014.

47. Khairoun I, Boltong MG, Driessens FC, Planell JA: Effect of calcium carbonate on clinical compliance of apatitic calcium phosphate bone cement. J Biomed Mater Res 1997, 38(4):356-360.

48. Clarkin OM, Boyd D, Madigan S, Towler MR: Comparison of an experimental bone cement with a commercial control, Hydroset. J Mater Sci Mater Med 2009, 20(7):1563-1570.

49. Constantz BR, Ison IC, Fulmer MT, Poser RD, Smith ST, VanWagoner M, Ross J, Goldstein SA, Jupiter JB, Rosenthal DI: Skeletal repair by in situ formation of the mineral phase of bone. Science 1995, 267(5205):1796-1799.

50. Morgan EF, Yetkinler DN, Constantz BR, Dauskardt RH: Mechanical properties of carbonated apatite bone mineral substitute: strength, fracture and fatigue behaviour. J Mater Sci Mater Med 1997, 8(9):559-570.

51. Moore DC, Frankenburg EP, Goulet JA, Goldstein SA: Hip screw augmentation with an in situ-setting calcium phosphate cement: an in vitro biomechanical analysis. J Orthop Trauma 1997, 11(8):577-583.

52. Urban RM, Turner TM, Hall DJ, Infanger SI, Cheema N, Lim TH, Moseley J, Carroll M, Roark M: Effects of altered crystalline structure and increased initial compressive strength of calcium sulfate bone graft substitute pellets on new bone formation. Orthopedics 2004, 27(1 Suppl):s113-118.

53. Boyd D, Towler MR, Wren A, Clarkin OM: Comparison of an experimental bone cement with surgical Simplex P, Spineplex and Cortoss. J Mater Sci Mater Med 2008, 19(4):1745-1752.

54. Huber FX, Belyaev O, Hillmeier J, Kock HJ, Huber C, Meeder PJ, Berger I: First histological observations on the incorporation of a novel nanocrystalline hydroxyapatite paste OSTIM in human cancellous bone. BMC Musculoskelet Disord 2006, 7:50

55. Huber FX, McArthur N, Hillmeier J, Kock HJ, Baier M, Diwo M, Berger I, Meeder PJ: Void filling of tibia compression fracture zones using a novel resorbable nanocrystalline hydroxyapatite paste in combination with a hydroxyapatite ceramic core: first clinical results. Arch Orthop Trauma Surg 2006, 126(8):533-540.

56. Huber FX, Hillmeier J, Kock HJ, McArthur N, Huber C, Diwo M, Baier M, Meeder PJ: [Filling of metaphyseal defects with nanocrystalline hydroxyapatite (Ostim) for fractures of the radius]. Zentralb/ Chir 2008, 133(6):577-581.

57. Huber FX, Hillmeier J, Herzog L, McArthur N, Kock HJ, Meeder PJ: Open reduction and palmar plate-osteosynthesis in combination with a nanocrystalline hydroxyapatite spacer in the treatment of comminuted fractures of the distal radius. J Hand Surg [Br] 2006, 31(3):298-303.

58. Jarcho M: Calcium phosphate ceramics as hard tissue prosthetics. Clin Orthop Relat Res 1981, , 157: 259-278.

59. Knop C, Sitte I, Canto F, Reinhold M, Blauth M: Successful posterior interlaminar fusion at the thoracic spine by sole use of beta-tricalcium phosphate. Arch Orthop Trauma Surg 2006, 126(3):204-210.

60. Dickson KF, Friedman J, Buchholz JG, Flandry FD: The use of BoneSource hydroxyapatite cement for traumatic metaphyseal bone void filling. J Trauma 2002, 53(6):1103-1108.

61. Mattsson P, Alberts A, Dahlberg G, Sohlman M, Hyldahl HC, Larsson S: Resorbable cement for the augmentation of internally-fixed unstable trochanteric fractures. A prospective, randomised multicentre study. J Bone Joint Surg Br 2005, 87(9):1203-1209.

62. Mattsson P, Larsson S: Stability of internally fixed femoral neck fractures augmented with resorbable cement. A prospective randomized study using radiostereometry. Scand J Surg 2003, 92(3):215-219.

63. Mattsson P, Larsson S: Unstable trochanteric fractures augmented with calcium phosphate cement. A prospective randomized study using radiostereometry to measure fracture stability. Scand J Surg 2004, 93(3):223-228

64. Horstmann WG, Verheyen CC, Leemans R: An injectable calcium phosphate cement as a bone-graft substitute in the treatment of displaced lateral tibial plateau fractures. Injury 2003, 34(2):141-144.

65. Simpson D, Keating JF: Outcome of tibial plateau fractures managed with calcium phosphate cement. Injury 2004, 35(9):913-918.

66. Elsner A, Jubel A, Prokop A, Koebke J, Rehm KE, Andermahr J: Augmentation of intraarticular calcaneal fractures with injectable calcium phosphate cement: densitometry, histology, and functional outcome of 18 patients. J Foot Ankle Surg 2005, 44(5):390-395.

67. Wee AT, Wong YS: Percutaneous reduction and injection of Norian bone cement for the treatment of displaced intra-articular calcaneal fractures. Foot Ankle Spec 2009, 2(2):98-106.

68. Robinson CM, Page RS: Severely impacted valgus proximal humeral fractures. Results of operative treatment. J Bone Joint Surg Am 2003, 85$A(9): 1647-1655$.

69. Jeyam M, Andrew JG, Muir LT, McGovern A: Controlled trial of distal radial fractures treated with a resorbable bone mineral substitute. $J$ Hand Surg Br 2002, 27(2):146-149.

70. Sanchez-Sotelo J, Munuera L, Madero R: Treatment of fractures of the distal radius with a remodellable bone cement: a prospective, randomised study using Norian SRS. J Bone Joint Surg Br 2000, 82(6):856-863.

71. Kopylov P, Aspenberg P, Yuan X, Ryd L: Radiostereometric analysis of distal radial fracture displacement during treatment: a randomized study comparing Norian SRS and external fixation in 23 patients. Acta Orthop Scand 2001, 72(1):57-61.

72. Kopylov P, Runnqvist K, Jonsson K, Aspenberg P: Norian SRS versus external fixation in redisplaced distal radial fractures. A randomized study in 40 patients. Acta Orthop Scand 1999, 70(1):1-5. 
73. Grafe IA, Baier M, Noldge G, Weiss C, Da Fonseca K, Hillmeier J, Libicher M, Rudofsky G, Metzner C, Nawroth P, et al: Calcium-phosphate and polymethylmethacrylate cement in long-term outcome after kyphoplasty of painful osteoporotic vertebral fractures. Spine (Phila Pa 1976) 2008, 33(11):1284-1290.

74. Libicher M, Hillmeier J, Liegibel U, Sommer U, Pyerin W, Vetter M, Meinzer HP, Grafe I, Meeder P, Noldge G, et al: Osseous integration of calcium phosphate in osteoporotic vertebral fractures after kyphoplasty: initial results from a clinical and experimental pilot study. Osteoporos Int 2006, 17(8):1208-1215.

75. Maestretti G, Cremer C, Otten P, Jakob RP: Prospective study of standalone balloon kyphoplasty with calcium phosphate cement augmentation in traumatic fractures. Eur Spine J 2007, 16(5):601-610.

76. Yu B, Han K, Ma H, Zhang C, Su J, Zhao J, Li J, Bai Y, Tang H: Treatment of tibial plateau fractures with high strength injectable calcium sulphate. Int Orthop 2009, 33(4):1127-1133.

77. Watson JT: The use of an injectable bone graft substitute in tibial metaphyseal fractures. Orthopedics 2004, 27(1 Suppl):s103-107.

78. Smit RS, van der Velde D, Hegeman JH: Augmented pin fixation with Cortoss for an unstable AO-A3 type distal radius fracture in a patient with a manifest osteoporosis. Arch Orthop Trauma Surg 2008, 128(9):989-993.

79. Andreassen GS, Hoiness PR, Skraamm I, Granlund O, Engebretsen L: Use of a synthetic bone void filler to augment screws in osteopenic ankle fracture fixation. Arch Orthop Trauma Surg 2004, 124(3):161-165.

80. Palussiere J, Berge J, Gangi A, Cotten A, Pasco A, Bertagnoli R, Jaksche H, Carpeggiani P, Deramond H: Clinical results of an open prospective study of a bis-GMA composite in percutaneous vertebral augmentation. Eur Spine J 2005, 14(10):982-991.

\section{Pre-publication history}

The pre-publication history for this paper can be accessed here: http://www.biomedcentral.com/1471-2474/12/34/prepub

doi:10.1186/1471-2474-12-34

Cite this article as: Van Lieshout et al: Microstructure and biomechanical characteristics of bone substitutes for trauma and orthopaedic surgery. BMC Musculoskeletal Disorders 2011 12:34.

\section{Submit your next manuscript to BioMed Central and take full advantage of:}

- Convenient online submission

- Thorough peer review

- No space constraints or color figure charges

- Immediate publication on acceptance

- Inclusion in PubMed, CAS, Scopus and Google Scholar

- Research which is freely available for redistribution

Submit your manuscript at www.biomedcentral.com/submit
Biomed Central 